\title{
CONSTITUTION.
}

\section{ARTICLE I.}

This Society shall be called the American Mathematical Society.

\section{ArTICLE II.}

The object of the Society shall be to encourage and maintain an active interest in mathematical science.

\section{Article III.}

The officers of the Society shall be a President, a VicePresident, a Secretary, a Treasurer, a Librarian, and a Committee of Publication to consist of three members who at the same time may hold individually any of the other offices.

\section{ARTICLE IV.}

The officers of the Society, together with nine other members, shall constitute a Council, which shall have general charge of the affairs of the Society.

\section{ArTicle V.}

I. The officers of the Society and three other members of the Council shall be elected by ballot at the Annual Meeting of each year. An official ballot shall be sent to each member at least one month prior to the Annual Meeting, and such ballots, if returned to the Secretary in envelopes bearing the names of the voters, shall be counted at the Annual Meeting. Each such ballot shall contain a name proposed by the Council for each vacancy, with blank spaces in which the voter may substitute other names. A majority of all votes cast in person or by mail shall be necessary to election. In case of failure to secure a majority for any office, the members present at the Annual Meeting shall choose by ballot between the two having the highest 
number of votes. The term of office shall be one year for officers and three years for other members of the Council, and until their successors shall be elected. No member shall be elected as President more than two years in succession. No elected member of the Council, having completed a term of three years, shall be re-elected until at least one year shall have intervened.

2. Such vacancies as may exist at any time among the officers shall be filled by the Council. If any elected member of the Council die or resign more than one year before the expiration of his term, the vacancy for the unexpired term shall be filled by the Society at the next Annual Meeting.

3. The existing Council shall continue until the next Annual Meeting, at which three groups, each of three nonofficial members of the Council, shall be elected, to serve respectively during terms of one, two and three years.

\section{ARTICLE VI.}

This Constitution shall not be amended unless notice of the proposed change be given in writing at a meeting of the Society, and such amendment receive the affirmative votes of four-fifths of the members present at the following meeting. 